\title{
Factors Affecting Ethnic Harmony between Sinhalese and Muslim Communities in Post-war Sri Lanka: A Study Based on South Eastern University of Sri Lanka
}

\author{
Ahamed Sarjoon Razick ${ }^{1}$, Mohamed Anifa Mohamed Fowsar ${ }^{2} \&$ Abdul Kalik Mihilar ${ }^{3}$ \\ ${ }^{1}$ Department of Islamic Studies, South Eastern University of Sri Lanka, Sri Lanka \\ ${ }^{2}$ Department of Political Science, South Eastern University of Sri Lanka, Sri Lanka \\ ${ }^{3}$ Department of Islamic Studies, Faculty of Islamic Studies and Arabic Language, Sri Lanka \\ Correspondence: Ahamed Sarjoon Razick, Department of Islamic Studies, South Eastern University of Sri Lanka, \\ Sri Lanka. E-mail: sarjoonra@seu.ac.lk
}

Received: September 15, 2020

Accepted: September 29, 2020

Online Published: October 13, 2020

doi:10.5539/jpl.v13n4p1

URL: https://doi.org/10.5539/jpl.v13n4p1

\begin{abstract}
Sri Lanka is home to multi-cultural communities. It is the responsibility of the people across various religions, and communities to develop and maintain harmony with each other. Historically, the Sri Lankan Muslims and Sinhala Buddhists had an excellent relationship. Recently, the ethnic harmony between these two communities has been strained reflecting the fault lines running in a current social structure which lead to ethnic tensions, social animosities, restlessness, and disharmony among communities, amidst diverging political ideologies. Hence, this study focuses on identifying the root causes that wreck the harmony and social stability of the country. Hundred and fifty students from the South Eastern University of Sri Lanka were randomly selected to respond for a structured questionnaire, and fifteen formal interviews with students were also conducted to validate the questionnaire data. The secondary data were collected from various sources of information. The collected data were analyzed using descriptive and basic statistical analytic techniques, and findings of the study were presented in the form of table and text. This study underlines the array of reasons, and root causes that prevent the harmony among Sinhala Buddhists and Muslim communities, such as ethnic differences, spreading hatred via social media, extremism that uses religion to forward their extremist ideologies. This study concludes with the argument that the government and people who strive for social harmony should act with commitment and dedication in the efforts to build harmony among religious communities in post-war Sri Lanka.
\end{abstract}

Keywords: Sri Lanka, ethnic harmony, Sinhala Buddhists, Muslims

\section{Introduction}

The national security of any country depends on its internal peaceful co-existence of multiple ethnicities and their ability to abide by peace and reconcile to maintain the equilibrium. A tiny island, Sri Lanka is known as home for some of the major ethnic groups such as Sinhalese, Muslims, Tamils, Burghers and Malays. The people are further categorized within religions such as Buddhists, Hindus, Muslims and Christians. Based on their archaeological evidence, these ethnic groups have a long history together co-existing among each other despite many unpleasant and hostile events flaring up often (Razick, 2015).

Sri Lanka historically had a good track record of maintaining social equilibrium and ethnic harmony between the Sinhalese Buddhists and Muslims. The Muslims got settled down across various regions of this country following a newfound relationship between the Arabs and Sinhalese. In the past, the Sinhala Buddhists and Muslims embraced each other's lives, culture with mutual respect and goodwill. The kings too had an affinity towards the Muslims. The Muslims too had repaid the faith and trust by uniting with other ethnic groups against the colonial masters to liberate the country and protect its sovereignty and integrity (Ali, 2014).

During the time of Monarchs, the Muslims lived with equal rights and privileges, and they were extremely loyal to them. Ones against instigating divisiveness, they opposed the Portuguese rule, their unlawful activities that adversely affected their land. Their loyalty shone brightly when they actively tried the advice and dissuaded the king Dharmapala's advisers not to permit the Portuguese to build a fort in their own land. When the country fell at 
the hands of colonial masters, the relationship between Muslims and Sinhalese was steady even when the Muslims never enjoyed equality during their reign. Their biggest concern was how the Portuguese and Dutch's rule had pushed the country into a period of darkness (Faleel, 2007).

When the British colonials took over the reins from the Portuguese and Dutch, they provided some respite to the Muslims. They officially and legally recognized them and repealed the law in 1832 enacted by the Dutch in 1747 that prohibited the Muslims to own land or house in forts or premises outside of the fort. They also offered them the freedom to worship in 1799. The British rule had its significance as it brought a lot of socio-economic and political reforms in the country. However, the rulers focused on divide and rule as an instrument of state policy to wedge into centuries-long peaceful co-existence (Sameem, 1997).

Some of their activities transformed Ceylon communities mobilizing them to enter politics. The government's adverse policies fueled religious and nationalist sentiments across the country, and subsequently, a lot of religious reformations happened through mass movements. Unfortunately, the bi-product of these events were polarizing, and at the beginning of the $20^{\text {th }}$ century, we witnessed a lot of hostile actions aimed at disrupting Sinhalese Muslim relations. One of the major riots in that context occurred in 1915 in Gampola, which was densely populated with Muslims and Sinhalese in the central province of Ceylon that triggered a collapse of the economy of Muslim community (Ali, 2015).

The British never owned their responsibilities and took remedial measures to curtail these riots. Instead, they let the riot spread across the country, which fortunately didn't spill over into the northern and eastern provinces. This was a bitter incident scarring the long-standing Sinhala - Muslim harmony (Najimudin, 2002). Following independence, the Ceylon government adopted several marginalization policies and took initiatives to exclude minorities from the mainstream of politics. Tamil minority, the most significant minority in the country, protested against the successive governments, which resulted in over three decades of civil war to establish a separate Tamil state in the island (Fazil, 2019).

An armed insurrection against the Sri Lankan military was led by the LTTE to establish their own homeland in the northern and eastern part of the country. Triggering a civil war, the country's ethnic relations scarring beyond repair and economic progress was severely stunted. Muslims willingly joined the Tamils with their struggle, but only through political recourse and not armed activities even as it severely affected their communities in those war-torn areas. Forceful evictions were key to the LTTE where the Muslims were the primary victims and every effort to bring this conflict to a peaceful end had failed which led to the war resuming in middle of 2006 until it came to its bloody end in 2009 ending the LTTE with it, in spite of the civil war creating opportunities for reconciliation (Rameez \& Fowsar, 2019).

The initiatives taken up by the government to reconcile and respond with positive and constructive actions to criticisms, there never was a genuine push to see those goals meet its logical conclusion. An example of that is when the government haplessly failed to rescue war victims. A new form of Sinhala Buddhist nationalism emerged after the war positioning them to be the flag bearers of newly-found religious nationalism, to occupy the vision of ordinary people. This developed only to target the Muslims, who were the second largest ethnic group, after the civil war. This resulted in the Sri Lankan Muslims facing an unprecedented crisis by being denied their cultural, economic, land rights etc. (Morrison, 2020; Rameez, 2018, Fowsar, 2014).

The politically motivated forces were able to create an unstable and extremely volatile state of affairs in the country. This presented an unprecedented challenge to the scarred and fractured relationship between the Sinhalese and Muslim communities. The most notable incident fueling the volatility was the suicide attack of 2019 has exacerbated anti-Muslim sentiments in the country (Imtiyaz, 2019). At this backdrop, this paper tries to discuss the factors affecting ethnic harmony between Sinhalese and Muslim communities.

\section{Research Methods}

The study aims to discuss and address the cause of unrest and factors affecting the ethnic harmony between Sinhalese and Muslim community in the post-civil war era. The tools and techniques using quantitative analysis were deployed in extracting information and detail that reflect ground reality and historical events as it is. For ease of activity, South Eastern University of Sri Lanka has been chosen for data collection and samples were collected to reflect the social diversity. One hundred and fifty students representing Sinhalese (75 samples) and Muslim (75 samples) communities were randomly selected to respond to the structured questionnaire and were uploaded to a database to get statistical outputs. A total of 15 interviews were conducted with ethnically diverse students to get valid results. These results are presented in table and text formats. This study is limited to validating the data that is collected between the periods of 2017-2019. 


\section{Results and Discussion}

Every ethnic community needs to cooperate by creating an atmosphere of harmony and mutual respect, sentiments and beliefs. In the same vein, it is also essential to address the issues that had or will continue to cause a rupture in the well laid out respectful environment preserved for centuries. Ideally, the post-war country could have always focused on restoring harmony and improve mutual support and cooperation. However, the ordinary men were influenced by rumors, misunderstanding, religious and economic factors, and was not helped by the media as well. The ethnic harmony after the civil war was threatened by the emergence of nationalist social forces severely hampering hopes of the revival. The other major obstacles were the politicians carrying out divisive political campaigns and activities to achieve their political aspirations.

The impact of journalists and their activities on social wellbeing of the nation through their media outlets such as print and visual can trigger or calm the groups. This depends on which side they pivot, but sadly they let go of that responsibility unlike the neutral voice of the voiceless. These complications were further worsened by the clergies who actively contributed to disharmony using their political background to advance their own agenda and interests at the expense of social and ethnic provocation. In the present scenario, this issue had a significant impact on the social harmony where the political motives of the individuals and academics were also intertwined, adding to the chaos. Hence, this paper attempts to discuss the key factors that affect the ethnic harmony in post-war Sri Lanka from an academic perspective as well.

\subsection{Ethnic Factors}

As a multi-cultural and ethnic country, Sri Lanka encompassed people with different origin, ethnicity, colour, language etc. The Buddhists and Muslims lived together in close circles and cooperated with each other in most areas such as politics, religion, economy, education, and culture. But the constant questioning and misplaced pride in identifying oneself by associating themselves with certain ethnicity. Thus, these factors have caused tension and threatening the prevailing peace between these communities. The major hindrance to progress is caused by the way the political, economic, and social structure is stacked. The reconciliation too takes a hit with how these are stacked unwittingly against each other, nulling each other's progress. To prevent this, following independence, various measures were taken that undermine the ethnic relationships prevailing at that time. Sadly, even today, to undermine the efforts, the ethnic factors are used as a tool to divide ethnic relations. In reference to the questionnaire data, students at large agree with ethnic factors have severely affected the harmony between two communities in post-war Sri Lanka. The table below illustrates the fact:

Table 1. Ethnic factors

\begin{tabular}{|c|c|c|c|c|c|c|}
\hline Statements & $\begin{array}{l}\text { Strongly } \\
\text { Agree }\end{array}$ & Agree & Neutral & Disagree & $\begin{array}{l}\text { Strongly } \\
\text { Disagree }\end{array}$ & Total \\
\hline $\begin{array}{l}\text { Harmony prevailed during the pre-war } \\
\text { period. }\end{array}$ & 52 & 55 & 43 & - & - & 150 \\
\hline $\begin{array}{l}\text { Harmony prevailed during the war } \\
\text { period. }\end{array}$ & 53 & 90 & 07 & - & - & 150 \\
\hline $\begin{array}{l}\text { Harmony prevailed during the post-war } \\
\text { period. }\end{array}$ & - & - & 06 & 118 & 26 & 150 \\
\hline Muslims are mostly loyal to the nation. & 10 & 30 & 24 & 48 & 38 & 150 \\
\hline Muslims are contributing to the nation. & 55 & 45 & 15 & 21 & 14 & 150 \\
\hline $\begin{array}{l}\text { Muslims have ties with Muslims } \\
\text { worldwide. }\end{array}$ & - & 09 & 26 & 80 & 35 & 150 \\
\hline $\begin{array}{l}\text { Muslims have been facing more } \\
\text { vulnerability in recent times. }\end{array}$ & 118 & 06 & 26 & - & - & 150 \\
\hline
\end{tabular}

Source: Questionnaire survey, 2019

The table above illustrates that most of the respondents agree that the ethnic harmony between Sinhalese and Muslim communities was firmly established during the pre-war and war period. Most of them also have further 
stated that in the current scenario, established principles of harmony and cooperation are in crisis. This points a decline in goodwill between the two communities after the civil war. The notion of Muslims being loyal to the country too was disputed by the participants where they informed that the Muslims are mostly loyal to their community now. An interviewee commented that "the core to all problems currently prevailing is due to ethnic identity. As the socio-political journey of post-war Sri Lanka revolves around it, spearheading ethnic identity becomes a leader-esque feature a politician hopes to step foot on pushing their political profile further up" (Interviewee 5).

The is also a notion prevailing around the Sri Lankan Muslims that they maintain connections with all the other Muslims across the world. It is claimed that a lot of extremist ideologies pass through these connections into the unwitting and ordinary Muslim, turning him into a potential target. Although the Muslim community is a part of the global Muslim Ummah, they are not supporters of extremist activities in Muslim countries. The analysis based on the questionnaire adds to the narrative where more than $50 \%$ of the participants deny that Sri Lankan Muslims maintain contact with Muslims worldwide. They also accept the fact that the place of Muslims in post-war Sri Lankan society is threatened pushing them to near vulnerability.

\subsection{Religious and Cultural Factors}

As all religions teach harmony, peace and reconciliation, the role played by religion is vital in regulating the social life of all communities and their spiritual lives. The core values across all religions preach that peace and prosperity should prevail in human life. Unfortunately, the preachers who play the role of flagbearers twist these facts to their benefit and to fit their narrative. People fail to realize that to prioritize their own faith and fundamental religious beliefs, and they do not need to demean or denigrate the beliefs of others. As we see in our recent past, religious factors have placed a key role in various clashes and violence in post-war Sri Lanka.

The rise of religious factors gaining political prominence is the direct result of the country's social structure. Interestingly Sri Lanka's independence struggle started with the various religious uprising against colonial masters. This also inadvertently spread the inter-ethnic tensions after the independence movement. Impulsive religious activities have impacted the seizure and retention model of political power. The communities' opinions were shaped by this impulsiveness, where they abandoned the idea of rekindling the social harmony. Hatred in the guise of religious identity and practices has inevitably got engraved into the ordinary Sri Lankan.

Table 2. Religious and cultural factors

\begin{tabular}{lcccccc}
\hline \multicolumn{1}{c}{ Statements } & $\begin{array}{c}\text { Strongly } \\
\text { Agree }\end{array}$ & Agree & Neutral & Disagree & $\begin{array}{c}\text { Strongly } \\
\text { Disagree }\end{array}$ & Total \\
\hline $\begin{array}{l}\text { Satisfaction with your religions and } \\
\text { their worship practices. }\end{array}$ & 52 & 55 & 43 & - & - & 150 \\
\hline $\begin{array}{l}\text { The misunderstanding of religion } \\
\text { incites religious fundamentalism } \\
\text { and radicalism. }\end{array}$ & 53 & 90 & 07 & - & - & 150 \\
\hline $\begin{array}{l}\text { Clergies have played a key role in } \\
\text { affecting Sinhala - Muslim } \\
\text { harmony. }\end{array}$ & - & - & 06 & 118 & 26 & 150 \\
\hline
\end{tabular}

Source: Questionnaire survey, 2019

According to the survey, all the participants were very satisfied with their freedom to practice their respective religions and religious practices. They also uphold that their aim through these practices is to promote harmony among other communities. But also have stated that the obsession with religion can incite hardline and fundamentalist thoughts and radicalization. The constant undermining of harmony and cooperation by religious fundamentalism had slowly started to become a new normal that the people unwittingly got accustomed to. There is a belief that the clergies and people collab together in spreading peace and harmony but the opposite trend continued where politicians peg their political background to advance their agenda by inciting the religious groups, they have a firm grip on. This manipulation tormented the social fabric of the country was built on (Table 2).

Priests and Clergies are presented with an unprecedented opportunity to be the guiding force they need to be in 
reducing the tension and promoting peace through cooperation. Instead, they become agents of chaos instigating riots and flaring communal tensions to keep their agenda and benefits at heart. This could not be far from making them traitors against their own community and to the country. A Sinhalese student commented that "the clergies through their radical thoughts erode significant goodwill towards other religion by promoting racist ideas. They were divisive and are the biggest barriers to progressive thinking. They try and achieve this agenda by constantly stoking and flaring communal unrest. The role of these clergy in moving the country forward in maintaining interethnic harmony is ambiguous. The government is reluctant to take action against them because they are influential in society" (Interviewee 3).

The emphasis on freedom of religious practice in Sri Lanka is a basic feature of social relations as it presents the framework to cooperate and accommodate various religious practices. In Sri Lankan context, the motivator for riots and unrest is stoked by the very conflicts between religions that could have been revolved only if the people are thinking progressively and are willing to reciprocate and reconcile whenever needed. It is also widely accepted that the cultural aspects of Islam and Buddhism are ethical and do not stand in the way of social harmony. Most of the respondents surveyed stated that cultural factors were an obstacle to Sinhala - Muslim harmony in post-war Sri Lanka, and significant differences in the cultural aspects of Muslims have caused a rift in harmony between the two communities.

\subsection{Political Factors}

One of the essential aspects and driver to ethnic harmony is their politics as we had witnessed through various pieces of evidence presented above. However, the politicians and their differences were never capable of staying on the same page and who previously played a crucial role in rallying people during pre-independence politics on real causes and reformations. Although there were several Sri Lankan Muslims who were part of successive independent governments, and in spite of playing a key role in determining the formation of the national government, little politically motivated instigation are still common feature for their political gain.

An interviewee shared that "the biggest obstacle to ethnic reconciliation in Sri Lanka is politics. By dividing the ethnic communities, the politicians reap the benefits for electoral gains by stoking riots. As the politicians felt there need to be segregation on ethnicity to maintain an upper hand for their political future. An unlikely solution to this could be where we need to unite the politicians towards a common cause rather focusing on their individual agenda. But the ones in power in Sri Lanka are doing one thing, and those in opposition are doing another. The rulingopposition parties are not working together on issues of national importance. Not only the national parties but also the minority parties are in a similar position. Only when this situation changes, reconciliation could be built in post-war Sri Lanka" (Interviewee 10).

Table 3. Political factors

\begin{tabular}{lcccccc}
\hline \multicolumn{1}{c}{ Statements } & $\begin{array}{c}\text { Strongly } \\
\text { Agree }\end{array}$ & Agree & Neutral & Disagree & $\begin{array}{c}\text { Strongly } \\
\text { Disagree }\end{array}$ & Total \\
\hline $\begin{array}{l}\text { The politicians are spearheads of } \\
\text { Sinhala - Muslim disharmony. }\end{array}$ & 70 & 58 & 15 & 07 & - & 150 \\
\hline $\begin{array}{l}\text { The politicians sabotage Sinhala - } \\
\text { Muslim harmony. }\end{array}$ & 37 & 84 & 29 & - & - & 150 \\
\hline $\begin{array}{l}\text { Emergence of ethnic parties is a } \\
\text { significant factor that undermines } \\
\text { ethnic harmony. }\end{array}$ & 65 & 35 & 21 & 19 & 10 & 150 \\
\hline
\end{tabular}

Source: Questionnaire survey, 2019

The activities unleashed by the politicians on the very social fabric that built this country, is the primary reason for disharmony as it reflects the thought process of most Sinhala - Muslim students who were surveyed. Adding to this, they also felt the greed of politicians for their vested interest and attempt to appease whoever they need to keep their political life afloat. This had sabotaged the harmony, as evidenced through the $2 / 3 \mathrm{rd}$ of the survey resonating the same. They also agree that ethnic-based political parties further deride the significance of existing harmony. 


\subsection{Economic Factors}

The economy plays a key role in returning normalcy to a country. The more people are keen to work and restore their livelihoods, the less they will be interested in anything else that can upset their rhythm, peace, and harmony. As they focus on restoring their livelihoods, they enter a productive phase and compete with each other in turn propelling the economy towards sustainability. Societal inequality is a direct output of economic inequality. Therefore, the economic factor is given prominence in studies related to conflict resolution, and there is also a greater emphasis on the economy in the peace building programs.

In Sri Lanka, we can see social inequalities by how the resources are spread out and accessible to their people. Few areas are blessed with more resources than the others. But the state machinery failed to realize the need to maintain equilibrium and the necessity to spread the resources so everyone can get equal opportunity to raise their lives out of shackles or instill sustained growth. But we could see a range of discrimination in how the resource is allocated where the decision is made on ethnic and cultural association of the recipient. The government did not help the cause where their economic policies pursued did not strengthen the social relationships, instead of causing more harm to it. They inadvertently reduced the economic strength of politically weak ethnic communities. This has significantly affected inter-ethnic harmony in the country.

Employment can alleviate a lot of financial stress for the people, and yet discrimination in that area too had caused unnecessary obstacle. Amidst the allegations that ethnic proportions are not adequately maintained in Sri Lanka's employment program within their system, they are accused of not providing the ethnic minorities with their deserved place in any state structure, especially in the military. Thus, ethnic discrimination and segregation policies displayed in the matter of employment have contributed to ethnic disunity. In a way, this was the reason for the over three-decade civil war in Sri Lanka. In terms of economy, Buddhists and Muslims played a key role in bolstering it. Muslims being a mercantile community, they excelled in maintaining trade relationships with other communities, especially Sinhalese. This enabled not only domestic but also their foreign trade to flourish. This helped the Muslims achieve higher economic status. But this historical fact is tweaked to support a false narrative that they use this to dominate the other communities. This made the Sinhalese feel that they are losing their ground to Muslims (Interviewee 16).

Commenting on this one interviewee said that "Sri Lanka's economic policies did not keep pace with the global political and economic changes. The elements of social relations were not included in Sri Lanka's economic policy goals. The government's efforts to improve the economy do not seem to have put much focus on the ethnic issue. Through various economic development undertakings, the post-war period yielded some success in strengthening social relations. The economy was a major factor in an overall deterioration of ethnic relations as the economy needs its people be healthy and socially united to work progressively and pull the economy upwards. As the communities get economically weaker, the more aggressive they get in protecting their lives and interests. Hardline social forces are working to instill fear among Muslims and crush the Muslim economy. The support received by mobs from the majority traders for the recent violence against Muslims shows the same. The economy is the root cause of the split between the Sinhala-Muslim people in Sri Lanka as a whole" (Interviewee 4).

Table 4. Economic factors

\begin{tabular}{llccccccc}
\hline \multicolumn{1}{c}{ Statements } & & $\begin{array}{c}\text { Strongly } \\
\text { Agree }\end{array}$ & Agree & Neutral & Disagree & $\begin{array}{c}\text { Strongly } \\
\text { Disagree }\end{array}$ & Total \\
\hline $\begin{array}{l}\text { Muslims have dominance in the Sri } \\
\text { Lankan economy. }\end{array}$ & 52 & 55 & 43 & - & - & 150 \\
\hline $\begin{array}{l}\text { Muslims businessman is that they } \\
\text { misbehave with their employee and } \\
\text { customers. }\end{array}$ & & & - & 07 & 53 & 90 & 150 \\
\end{tabular}

Source: Questionnaire survey, 2019

A majority of respondents of the questionnaire analysis had the opinion that the Muslims have dominance in Sri Lankan economy. The common misconception that economic development of the Muslims will lead to the subjugation of the Sinhalese people to them. These speculations are used to mobilize and radicalize them to take in the attacks against Muslims. In reference to the above table (4), after the war, there has been a significant decline 
in good purchased from the Muslim merchants and from their establishments. As various forms of attack are targeted against them due to misconceptions, they as a community had to suffer. Violence against Muslims has also created fear among Muslim businessmen and forced to abandon their businesses in various parts of the country.

Another allegation leveled against Muslims businessman is that they misbehave with their employee and customers. Based on the data gathered in this case, 75 percent of respondents strongly disagree with the above allegation. Many feel that such misconceptions are spread because of commercial competitions. According to many of those interviewed, they said that Muslim businessmen for treating their employees and customers well. They argued that they generalize individual incidents to create unwanted issues among different communities. They also pointed out that the competition between Sinhala-Muslim traders is the reason for all these problems (Interviewee 7).

\subsection{Media Factors}

Media had the power to positively influence an entire community or bunch of communities. Mass media reach in recent years has been unprecedented. News published by the media has the power to invade culture easily. Social media is especially crucial in the line of changes that have taken place in today's media technology. The youth are enamored by the social media has been responsible for mobilizing for many positive causes in other parts of the contemporary world. As media extends its influence in socio-political life, it acts as an instrument of public opinion reflecting their need on various requirements. It is safe to say that media has a significant impact on the sociopolitical landscape of Sri Lanka society.

What's trending in media recently in Sri Lanka is not most satisfactory. The media forgot their impact on socioeconomic landscape. By painting political shades and associating them with any of the active political parties for business reasons, they engage in activities that foster animosity among communities instead of promoting ethnic harmony. Rumors and false propaganda are carried to the people through the media. The media failed to realize their social responsibility and how they could have constructively engaged in activities that promote harmony and cooperation among communities. Instead, they jump at the first opportunity to broadcast inter-ethnic conflict, hastily publish fake news without proper investigation, and re-publish news that emphasizes religious and culturally sensitive issues

The media being common and within reach of every common men and women, they are being used as a tool in provoking the recent Sinhala-Muslim riots in Sri Lanka. Unrestricted reach and availability had given the opportunity to anti-social groups to use social media extensively to spread misinformation about Muslims among the Sinhalese people. The Sri Lankan government had temporarily suspended the use of social media during the recent riots in Sri Lanka. This prevented the spread of false news and the rise of violence in that time. Even in recent years some people use social media to fragment communities, even under normal circumstances. Any media that operate through a political prism conducting various programs to help their parties' vested interests for political gains have increased exponentially. Prioritizing religious and ethnic issues during election became common trend without realizing the danger of stoking violence inadvertently. Such a situation was widely observed during the recent national elections in Sri Lanka. The media plays with every awareness that it can cause of the collapse of order and peace (Interviewee 11).

Commenting on the impact of the media on social harmony, an interviewee said that "the contribution of the media to social cohesion is essential. Most people in Sri Lanka have very close contact with the media. Social media usage has also ballooned in Sri Lanka. But performing these media is unfortunate. Sri Lanka's media is divided along ethnic, religious, cultural, and political lines. There is no general policy for the media. The ruling parties also seek to use the media to their advantage. Those in power sometimes restrict media freedom. Sometimes, the media publishes false news for the sake of their popularity. The media also plays a role in making an inconsiderable matter as a big issue. The media shows ethnic and religious discrimination in publishing news. Such media culture is a major obstacle to Sinhala-Muslim harmony in Sri Lanka" (Interviewee 12).

Table 5. Media factors

\begin{tabular}{ccccccc}
\hline \multicolumn{1}{c}{ Statements } & $\begin{array}{c}\text { Strongly } \\
\text { Agree }\end{array}$ & Agree & Neutral & Disagree & $\begin{array}{c}\text { Strongly } \\
\text { Disagree }\end{array}$ & Total \\
\hline $\begin{array}{l}\text { Activities of media affect the harmony } \\
\text { between Sinhalese and Muslim } \\
\text { communities in post-war Sri Lanka. }\end{array}$ & & & & - & - & 150 \\
\hline
\end{tabular}

Source: Questionnaire survey, 2019 
According to the questionnaire survey, 21 percent strongly agree that the media contributes to Sinhala-Muslim disharmony in post-war Sri Lanka. 51\% of people agree with this opinion. But 28 percent did not want to register an opinion in this regards. Thus it can be pointed out that the activity of the media is a major factor affecting Sinhala-Muslim harmony in post-war Sri Lanka (Table 5).

\subsection{Misconception and Rumors}

Key factors affecting harmony are misconceptions and rumors. In post-war Sri Lanka, most of the interviewees agreed that speculations and misconceptions due to lack of awareness contribute to Sinhalese-Muslim disharmony. These misconceptions can infiltrate every community and can foster prejudices and increase ethnic divisions. Rumors also enable misunderstandings among communities. According to table 6, 28 respondents strongly and 65 respondents agree that misconceptions and rumors severely affect social harmony. But 57 respondents did not comment on the particular statement. 107 respondents strongly and 43 respondents agree that misconceptions and rumors infiltrate society, distort social understanding and foster ideological differences.

Table 6. Misconception and rumors

\begin{tabular}{lcccccc}
\hline \multicolumn{1}{c}{ Statements } & $\begin{array}{c}\text { Strongly } \\
\text { Agree }\end{array}$ & Agree & Neutral & Disagree & $\begin{array}{c}\text { Strongly } \\
\text { Disagree }\end{array}$ & Total \\
\hline $\begin{array}{l}\text { Misconceptions and rumors severely affect } \\
\text { the harmony between Sinhala and Muslim in } \\
\text { post-war Sri Lanka. }\end{array}$ & 28 & 65 & 57 & - & - & 150 \\
\hline $\begin{array}{l}\text { Misconceptions and speculations infiltrate } \\
\text { communities, foster prejudices, and increase } \\
\text { ethnic divisions and misunderstandings. }\end{array}$ & 107 & 43 & - & - & - & 150 \\
\hline
\end{tabular}

Source: Questionnaire survey, 2019

When asked about those who spread misconceptions and rumors, 28 percent said that politicians are the ones who spread misconceptions and rumors. Political parties are instilling misconceptions about other ethnic groups among their respective communities for political gain. It is possible to observe that politicians are more involved in such activities during the election period. The results of the study show that politically motivated clergy are also at the forefront of spreading misconceptions and rumors. According to the survey, 14 percent of the respondents had such an opinion. Apart from these two groups, journalists (17\%), writers (19\%), civil society organizations (13\%) and individuals (9\%) also spread misconceptions and rumors among the community (Table 7).

Table 7. Relevant parties relating to misconceptions and rumors

\begin{tabular}{lc}
\hline \multicolumn{1}{c}{ Relevant parties } & Percentage \\
\hline Politicians & 28 \\
Clergies & 14 \\
Journalists & 17 \\
Writers & 19 \\
Civil society organizations & 13 \\
Individuals & 09 \\
\hline
\end{tabular}

Source: Questionnaire survey, 2019

Thus, the spread of misconceptions and rumors by various sections of the society has a more significant impact among the ordinary people and foster misconceptions about other ethnicities and sects. We can identify this out as one kind of issue that has affected the harmony between Sinhala Buddhists and Muslims in Sri Lanka in recent times. Those who spread these ideas are distracting people for their own vested interests and achieve their own callous goals. The benefits of the individuals and groups concerned are reaped through spreading racist and 
religious misconceptions among the people and convincing them.

Commenting on this in an interview, an interviewee said, "In a recent campaign about the rapid increase of Muslim population, the common perception was that Muslims are growing significantly in Sri Lanka's population and that Muslims will become the majority in the future. It is also widely suggested that contraceptives are served in Muslim hotels to reduce the birth rate of other ethnic groups. Although this view is not true, many ordinary people believe it, and these misconceptions have had a significant impact on the relationship of the Sinhalese people with Sri Lankan Muslims" (Interviewee 9).

As misconceptions continue to prevail, the religious and civil society leaders didn't put enough to alleviate this to ensure, people are open to cooperation. Instead led this prevalent thought spread across the region. Media too is a party to this misinformation where, they had the key to help those people see firsthand what they need to learn and understand to remove these misconceptions. Unfortunately, the ethnic riots always flare up when enough steps are not taken to alleviate misconceptions. As we look at the statistics, the apparent that these are not valid comments. Yet there is a matter of deliberate influence on the life of the people and their social relationships

\section{Conclusion}

Ethnic harmony is one of the most crucial topics in multi-ethnic countries. The importance of ethnic harmony has historically been a success story in Sri Lanka. However, the following colonial rule had a significant negative impact on ethnic harmony has caused fissures and created ethnic polarizations among Sri Lankan communities. Especially after the civil war, ethnic harmony between Sinhala and Muslims has been steadily declining. There have been several riots between both communities in recent years. In reference to this context, this study focuses on the ethnic harmony between the Sinhalese and Muslim communities in post-war Sri Lanka. This study highlights the historical relationship between the two communities and analyzes the factors that have particularly affected ethnic harmony in the present.

This study shows that the relationship between Sri Lankan Muslims and Sinhalese was excellent during the war and in the pre-war period. From the data collected for the study, it found that there is a significant gap in SinhalaMuslim ethnic harmony in the post-war period. The study reveals that political factors play a crucial role in affecting ethnic harmony. Most of those selected for the study prioritizes political factors. Further analysis shows political extremists fostering those hostile sentiments for their own political interests. Similarly, the activities of the media have had a significant impact on the Sinhala-Muslim relationship. Half of those surveyed believe that the media plays a vital role in disturbing social harmony. Rumors, misunderstandings, economics, religion, culture and ethnicity are other leading causes that interrupt the harmony among Sinhala Buddhists and Muslim communities.

The paper summarizes the major findings of the study: Ethnic harmony between Sinhala-Buddhists and Muslims was maintained at the highest level in most aspects of politics, economy, religion, culture and race during the civil war; Even today, ordinary Sinhala-Muslim people maintain respectful relations between them in many areas of the country; Most of Sinhala-Muslim people are very concerned about their religion, and both faiths never taught to instill disharmony and threats to each other's' livelihood. The rise of religious extremism among both communities is an obstacle to social harmony, and the recent riots illustrate the fact; raised misconceptions about other communities among each community and such mistakes severely affect social harmony; the hate propaganda of the religious leaders is another major factor affecting inter-ethnic harmony in post-war Sri Lanka; Easter suicide attack of so-called Muslim youths has fueled anti-Muslim sentiments among the Sinhalese community in the recent past.

The study further reveals significant points: Although respondents are satisfied with the religions of the two communities, some hold the view that religious diversity is an obstacle to ethnic harmony in the country; There is widespread extremist propaganda against Muslims across the country in the recent past; Muslim women's dress code, Halal certification and slaughtering animals have been the subject of criticism. However, both communities should come forward and be mutually respectful of each other's culture and reciprocate goodwill and harmony. This, in turn, will be a factor to be celebrated elevating their contribution and cooperation towards economic contribution as well. Due to misinformation and misplaced beliefs, an unwanted rivalry has been stoked. Instead, it's imperative to hold on the very fabric that united these two communities.

In a war-torn country, ethnic harmony is essential the development. The ethnic communities need to be open to reciprocate and treat others with mutual respect. This enables them to weed out any differences and lead the country to a path of sustained development and success. The government should not miss out on capitalizing positive opportunity and identifying factors that can affect ethnic harmony and move the country forward. 


\section{References}

Ali, A. (2014). Muslims in harmony and conflict in plural Sri Lanka: A historical summary from a religio-economic and political perspective. Journal of Muslim Minority Affairs, 34(3), 227-242. https://doi.org/10.1080/13602004.2014.939554

Ali, A. (2015). Four waves of Muslim-phobia in Sri Lanka: c.1880-2009. Journal of Muslim Minority Affairs, 35(4), 486-502. https://doi.org/10.1080/13602004.2015.1112116

Faleel, S. H. M. (2007). Peaceful co-existence of Sri Lankan Muslims. Islamic Thought, 3-9.

Fazil, M. M. (2019). State-minority contestations in post-colonial Sri Lanka. Journal of Educational and Social Research, 9(4), 157-165. https://doi.org/10.2478/jesr-2019-0065

Fowsar, M. A. M. (2014). Religious symbolism and politics in Sri Lanka: Muslim's grievances. Proceedings of first international Symposium of Faculty of Islamic Studies and Arabic Language, South Eastern University of Sri Lanka: 32-35. Oluvil, Sri Lanka: South Eastern University of Sri Lanka.

Imtiyaz, A. R. M. (2020). The Easter Sunday bombings and the crisis facing Sri Lanka's Muslims. Journal of Asian and African Studies, 55(1), 3-16. https://doi.org/10.1177/0021909619868244

Morrison, C. (2020). Buddhist extremism, anti-Muslim violence and civil war legacies in Sri Lanka. Asian Ethnicity, 21(1), 137-159. https://doi.org/10.1080/14631369.2019.1610937

Najimudeen, A. M. (2002). Riots and Muslims. Colombo: Milax Graphics.

Rameez, A. (2018). Resurgence of ethno-religious sentiment against Muslims in Sri Lanka: Recent anti-Muslim violence in Ampara and Kandy. Journal of Politics and Law, 11(4), 27-39. https://doi.org/10.5539/jpl.v11n4p27

Rameez, M. A. M., \& Fowsar, M. A. M. (2019). Forceful expulsion of Muslims from northern Sri Lanka: Thirty years of struggle for resettlement. Abstract Proceedings of International Seminar on Forced Migrants, Refugees, Welfare Policies and the State, Organized by Department of Sociology, University of Kerala, Thiruvananthapuram, India.

Razick, A. S., Long, A. S., \& Salleh, K. (2015). Historical relationship between the Buddhists and the Muslims in Sri Lanka. Mediterranean Journal of Social Sciences, 6(4), 278-284. https://doi.org/10.5901/mjss.2015.v6n4s2p278

Sameem, M. (1997). Problems of a minority community. Colombo: Islamic Book House.

\section{Copyrights}

Copyright for this article is retained by the author(s), with first publication rights granted to the journal.

This is an open-access article distributed under the terms and conditions of the Creative Commons Attribution license (http://creativecommons.org/licenses/by/4.0/). 